Seamer, J. (1959). J. gen. Microbiol. 21, 344-351

\title{
The Propagation and Preservation of Eperythrozoon coccoides
}

\author{
BY J. SEAMER \\ Department of Animal Pathology, School of Veterinary Medicine, \\ University of Cambridge
}

\begin{abstract}
SUMMARY: The propagation of Eperythrozoon coccoides in embryonated hen eggs inoculated by the yolk sac and intravenous routes is recorded. Fourteen continuous serial passages were made in the yolk sac and sixteen passages were made after intravenous inoculation into the chick embryo. The mortality among infected embryos was low; splenic enlargement was the only lesion detected. Once the strain had become established. $\boldsymbol{E}$. coccoides was seen in blood smears taken from some eggs after each passage. Yolk sac or blood from infected embryos proved to be infective for mice on each occasion they were examined; $10^{-6}$ dilutions of yolk sac were also infective. $E$. coccoides was preserved for short periods at $-30^{\circ}$ in mouse and chickembryo blood, but not in yolk sac. The organism was also preserved in mouse blood and chick-embryo tissues at $-79^{\circ}$. The presence of $10 \%(\mathrm{v} / \mathrm{v})$ sterile glycerol appeared to increase the stability of $E$. coccoides in chick-embryo tissues stored at $-\mathbf{7 9}^{\circ}$.
\end{abstract}

No reports were found in the literature about the propagation of any species of eperythrozoa in the laboratory. The limited host range of this group of organisms has made their manipulation difficult and satisfactory methods of cultivation and preservation should afford an opportunity to extend our knowledge of them. This report records the successful propagation of Eperythrozoon coccoides in embryonated eggs inoculated by the yolk sac and intravenous routes, and the preservation of this organism at $-30^{\circ}$ and at $-79^{\circ}$.

\section{METHODS}

The strain of Eperythrozoon coccoides Schilling, 1928, used was obtained from mice at the Molteno Institute, University of Cambridge, by courtesy of Dr June Thurston.

Albino mice (c. 20 g.) from a strain infected with Eperythrozoon coccoides were used to examine the infectivity of the early passages in chick embryos inoculated by the intravenous route. The albino mice were splenectomized and blood smears taken from them for examination on three alternate days in each week for a 10 day period before inoculation, in order to detect carriers. Subsequently, VS mice (from the National Institute for Medical Research, Mill Hill, through the courtesy of $\operatorname{Dr} A$. W. Gledhill) which are normally free from E. coccoides, were used for all experiments. Splenectomized VS mice (c. 15-20g.) were used to examine the infectivity of the later intravenous passages, and for all the yolk-sac passages; they were also used in the early experiments with preserved materials. Intact VS mice were used for the later experiments with preserved materials and for the titrations. Each mouse received a standard 
inoculum of $0.5 \mathrm{ml}$. by intraperitoneal injection. The experimental groups consisted of three inoculated mice and one control mouse. Only two mice were inoculated with the chick embryo blood harvested after each passage, and one control was kept with every six or fewer inoculated mice in the titration and preservation experiments. Blood smears were taken for examination three times weekly. All mice were treated weekly with benzene hexachloride to control ectoparasites.

The techniques used with embryonated eggs were essentially those of Beveridge \& Burnett (1946). The eggs were incubated at $35 \cdot 5^{\circ}$; deaths within $48 \mathrm{hr}$. of inoculation were ignored. Crystalline sodium penicillin $\mathrm{G}$ and streptomycin sulphate were added to all inocula to give final concentrations of $100 \mathrm{i} . \mathrm{u}$. and $100 \mu \mathrm{g} . / \mathrm{ml}$., respectively. The initial inocula consisted of heparinized mouse blood heavily infected with Eperythrozoon coccoides. Dead embryos, and viable embryos from the later passages, were dissected. All passages with embryonic material were made immediately after harvesting.

Batches of six embryonated eggs which had been incubated for 6-8 days were inoculated with $0.25 \mathrm{ml}$. into the yolk sac. An uninoculated egg was kept with each batch. After each passage, blood and yolk-sac smears were obtained from each egg; portions of yolk and yolk sac were pooled and chopped finely with scissors and suspensions were prepared in sterile Craigie mincers (Craigie, 1949). These suspensions, which contained only yolk, yolk sac and added antibiotics, are subsequently referred to as 'yolk sac'. Serial dilutions of infected yolk sac from the twenty-third and twenty-fifth passages were made in heart infusion broth containing $10 \%(v / v)$ horse serum, the whole diluted with an equal volume of normal saline. The suspensions were prepared at room temperature immediately after harvesting and mice were inoculated with $1 / 100$ dilutions as soon as possible.

Embryonated eggs which had been incubated for 10-12 days were inoculated intravenously with $0.05 \mathrm{ml}$. Owing to a varying mortality after inoculation, a standard number of eggs was not used for each passage. At harvesting, the shell membranes were clarified with heparinized phosphate buffered saline ( $\mathrm{pH} 7 \cdot 2 ; 20$ i.u. heparin $/ \mathrm{ml}$.). Blood smears were made from undiluted blood as far as possible. The blood from all the eggs of each passage was collected, with about $2 \mathrm{ml}$. heparinized saline. Embryonic blood containing heparinized saline, penicillin and streptomycin is subsequently referred to as 'chick-embryo blood'. For control material, blood smears were taken from three batches of ten normal embryonated eggs.

For the preservation experiments, heparinized and defibrinated blood and serum were obtained by bleeding out splenectomized mice heavily infected with Eperythrozoon coccoides; infected yolk sac and chick-embryo blood were obtained from the serial passages in eggs. The chick-embryo tissues always contained added antibiotics, and chick-embryo blood also contained the heparinized saline with which it was harvested. The tissues were stored in $5 \mathrm{ml}$. screw-capped bottles; most of those stored at $-79^{\circ}$ had a gas-tight seal of wax between the lid and the bottle. When required for use the samples were thawed in warm tap water. 
Smears of mouse blood and of chick-embryo tissues were made on clean grease-free slides. The smears were fixed in methanol and were stained whilst inverted upon curved glass staining trays with Giemsa's stain diluted 1/16 with phosphate buffer ( $\mathrm{pH} \mathrm{7 \cdot 2)}$ ). Mouse blood smears were stained for $45 \mathrm{~min}$. and chick-embryo tissues for $3 \mathrm{hr}$. The smears were rinsed briefly in phosphate buffer after staining and were allowed to dry over an electric lamp.

\section{RESULTS}

The survival of Eperythrozoon coccoides in embryonated eggs inoculated into the yolk sac

Four groups of four embryonated eggs were inoculated into the yolk sac with Eperythrozoon coccoides in heparinized mouse blood. The eggs were harvested after further periods of incubation of 3, 5, 7 and 10 days. Yolk sac from each group of eggs was inoculated into mice. All the embryos survived until they were harvested. All the inoculated mice developed infections of $\boldsymbol{E}$. coccoides after prepatent periods of 2-4 days. None of the control mice became infected. These results suggested that $E$. coccoides might be conveniently passaged in the yolk sacs of embryonated eggs at weekly intervals.

\section{The propagation of Eperythrozoon coccoides in the yolk sacs of embryonated eggs}

Embryonated eggs were inoculated with mouse blood heavily infected with Eperythrozoon coccoides. This blood was obtained from a mouse inoculated with yolk sac from eggs incubated for 7 days in the earlier experiment. Passages were made at weekly intervals. Three mice were inoculated with yolk sac after each passage except the sixth, eighth, eleventh and thirteenth. Only two mice were inoculated after the ninth passage.

Seven days after inoculation with Eperythrozoon coccoides, two of the embryos used for the first passage died. Accordingly, the four viable embryos and the two dead ones were harvested separately, and further eggs and mice were inoculated from each group. Yolk sac from the two dead eggs infected mice with $\boldsymbol{E}$. coccoides. The eggs inoculated with similar material survived for 7 days, yolk sac taken from them failed to infect mice. Yolk sac from the four surviving eggs in the first passage infected mice with $E$. coccoides after prepatent periods of 2 days. From this material, 14 continuous serial passages were made at weekly intervals in the yolk sacs of embryonated eggs. Bacterial contamination interrupted the series at the fifteenth passage. Subsequent passages from stored material have brought the total number of passages to 25.

During the 14 passages 96 embryos were inoculated; 10 of these failed to survive for $48 \mathrm{hr}$. after inoculation. Only 9 of the remaining 86 embryos did not survive until they were required for harvesting. Two embryos died during the first and thirteenth passages, and one embryo died in each of the eighth, ninth, tenth, eleventh and fourteenth passages. All the deaths occurred on the sixth or seventh day after inoculation, except one, which occurred on 
the fourth day. At the tenth passage 18 eggs were inoculated, and the incubation of 9 embryos which had survived for 7 days after inoculation was continued, but none hatched. None of the 14 uninoculated embryos died during the period permitted for incubation.

Each of the dead embryos had haemorrhagic lesions. Splenic enlargement was present in two of the nine embryos which died before harvesting and in five of the nine embryos whose incubation was prolonged at the tenth passage. Lesions in viable infected embryos were not investigated during the first 10 passages. Eighteen viable infected embryos were examined at the eleventh to fourteenth passages. Variable degrees of splenic enlargement were found in 16 of these embryos, as judged by comparison with the controls.

Blood smears were obtained from 53 embryos inoculated from the fifth passage onwards. Structures morphologically indistinguishable from Eperythrozoon coccoides were seen in 44 smears. The organisms were distributed on and between the erythrocytes, so that smears of infected chick-embryo blood closely resembled blood smears from infected mice. Large numbers of organisms were occasionally seen. No structures identifiable as $\boldsymbol{E}$. coccoides were detected in blood smears taken from 11 uninoculated eggs or from 12 hens of the laying flock.

Occasional structures resembling the annular forms of Eperythrozoon coccoides were seen in yolk-sac smears. After the eleventh, thirteenth and fourteenth passages large numbers of these structures were seen in smears made from some inoculated eggs. Although similar structures were never seen in large numbers in smears made from uninoculated eggs, the identity of these rings remains uncertain.

Spleen impression smears were obtained from 17 viable infected embryos of the eleventh to the fourteenth passages. In each case annular organisms were detected in the thinner portions of the smears, and occasionally an infected erythrocyte was seen. No association of the organisms and spleen cells was observed. No organisms were detected in spleen smears made from uninoculated embryos.

Twenty-nine mice were inoculated after the various passages. Apart from three mice which died too soon after inoculation for the infection to manifest itself, all the inoculated mice became infected with Eperythrozoon coccoides after prepatent periods of 2-4 days; none of the control mice became infected. Yolk sac harvested after the twenty-third and twenty-fifth passages was infective in $10^{-6}$ dilutions; one of three mice which received a $10^{-8}$ dilution of twenty-fifth passage material also became infected with $\boldsymbol{E}$. coccoides. The other five mice which received $10^{-8}$ and $10^{-10}$ dilutions, and the controls, remained free of infection. In these and in other titrations it was noted that the length of the prepatent periods varied according to the dose of $E$. coccoides received, and corresponded approximately to the logarithm of the dilution used, e.g. $10^{-2}$ and $10^{-4}$ dilutions frequently resulted in prepatent periods of 2 and 4 days. 
The propagation of Eperythrozoon coccoides in embryonated eggs inoculated by the intravenous route

A preliminary experiment showed that Eperythrozoon coccoides survived for at least 5 days in embryonated eggs after intravenous inoculation. Accordingly passages at 5-day intervals were undertaken. At the sixth passage some inoculated eggs were harvested after 5 days and passaged, but when it was found that the remaining eggs, harvested after 7 days, were also infected with $E$. coccoides, all subsequent passages were made at weekly intervals. Two mice were inoculated with chick-embryo blood after each of the first six passages, and after each subsequent even numbered passage.

Eperythrozoon coccoides was carried through 16 continuous serial passages in chick embryos inoculated by the intravenous route. During the 16 passages 88 embryos survived for more than $48 \mathrm{hr}$. after inoculation; only seven of these embryos died before they were required for harvesting. The incubation of eight surviving embryos of the fourteenth passage was prolonged, but none hatched. These embryos, and four others which died 3 and 4 days after inoculation in the ninth, tenth and eleventh passages, were not examined. One embryo died in the thirteenth passage and two in the fifteenth passage, 6 and 7 days after inoculation. These three embryos, and nine viable embryos from the thirteenth, fourteenth and sixteenth passages, were dissected. The three dead embryos and four viable ones had enlarged spleens, but no other lesions were observed.

Eperythrozoon coccoides was detected in 41 of 74 blood smears which were obtained during the sixteen passages. The number of organisms present varied from very few to very many. Eperythrozoa were not seen in smears taken from eggs harvested during the first three passages. A smear from one embryo harvested at the fourth passage contained visible organisms, as did the smears from three of the five embryos harvested at the fifth passage. Subsequently eperythrozoa were detected in smears from most, but not all, of the inoculated embryos. No structures identifiable as $\boldsymbol{E}$. coccoides were seen in blood smears obtained from 30 normal embryos which had been incubated for 18 days.

Eperythrozoa were detected in six spleen smears obtained from viable embryos of the later passages. No association between the organisms and spleen cells was found.

Chick-embryo blood was inoculated into 22 mice. All the mice became infected with Eperythrozoon coccoides except one, which died before manifesting the infection. The prepatent periods ranged from 2 to 5 days, but in those mice in which, owing to the system of thrice-weekly bleeding, E. coccoides was first detected 5 days after inoculation, the infection was usually well established. The control mice, with one exception, remained free of infection. One blood smear obtained from an uninoculated VS mouse contained $\boldsymbol{E}$. coccoides, but since earlier and subsequent smears did not contain organisms, it was possible that this mouse was not infected. 
The viability of Eperythrozoon coccoides at $-30^{\circ}$ and at $-79^{\circ}$

Viability at $-30^{\circ}$. Samples of heparinized and defibrinated blood and serum infected with Eperythrozoon coccoides were placed in a refrigerator at $-30^{\circ}$. After storage for 8 days each sample was thawed and mice were inoculated. The inoculations were completed within $30 \mathrm{~min}$. and the residual materials were again stored at $-30^{\circ}$. After a further 36 days the samples were thawed again and further mice received the following inocula: heparinized blood $0.5 \mathrm{ml}$., defibrinated blood $0.4 \mathrm{ml}$. and serum $0.3 \mathrm{ml}$.

The inocula of heparinized blood, defibrinated blood and serum which had been stored for 8 days infected mice with Eperythrozoon coccoides after pre-

Table 1. The infectivity of Eperythrozoon coccoides after storage in mouse blood and chick-embryo materials at $-30^{\circ}$

Inoculum

Heparinized mouse blood

Defibrinated mouse blood

Mouse serum

Heparinized mouse blood*

Defibrinated mouse blood*

Mouse serum*

Chick-embryo blood

(5th passage)

Chick-embryo blood

(6th passage)

Yolk sac (6th passage)

Yolk sac (4th passage)
Duration of . Infectivity storage (days) for mice

$\begin{array}{rr}8 & + \\ 8 & + \\ 8 & + \\ 44 & + \\ 44 & + \\ 44 & + \\ 29 & - \\ 71 & - \\ 14 & -\end{array}$

* Had been once thawed and frozen again whilst stored. $+=$ infective; $-=$ not infective.

Table 2. The infectivity of Eperythrozoon coccoides after storage in mouse blood and chick-embryo materials at $-79^{\circ}$

Inoculum

Mouse blood + glycerol

Mouse blood

Mouse blood + glycerol

Mouse blood

Chick embryo blood (8th passage) + glycerol

Chick embryo blood (8th passage)

Chick embryo blood (11th passage)

Chick embryo blood (9th passage)

Chick embryo blood (16th passage) + glycerol

Yolk sac (9th passage) + glycerol

Yolk sac (9th passage)

Yolk sac (12th passage) + glycerol

Yolk sac (13th passage)

Yolk sac (21st passage) + glycerol

Yolk sac (24th passage) + glycerol

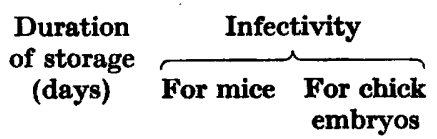

$\begin{array}{rcc}12 & + & \text { n.t. } \\ 12 & + & \text { n.t. } \\ 82 & + & \text { n.t. } \\ 32 & + & \text { n.t. } \\ 8 & + & \text { n.t. } \\ 8 & + & \text { n.t. } \\ 14 & + & + \\ 36 & - & \text { n.t. } \\ 19 & + & + \\ 8 & + & + \\ 8 & +* & - \\ 19 & + & + \\ 12 & + & + \\ 49 & + & + \\ 92 & + & +\end{array}$

* Infected two of three mice inoculated. $+=$ infective; $-=$ not infective; n.t. = not tested. 
patent periods of three days. After storage for 44 days, during which time they had once been thawed and frozen again, heparinized blood and defibrinated blood infected mice after prepatent periods of four days. The serum which had been similarly treated was no longer infective. This experiment and four others with chick embryo tissues are summarized in Table 1.

Viability at $-79^{\circ}$. The viability of Eperythrozoon coccoides was examined with and without the addition of $c .10 \%(\mathrm{w} / \mathrm{v})$ sterile glycerol. Glycerol was added little by little to infected mouse blood, which was then cooled to $-79^{\circ}$ at a rate of $2^{\circ}$ to $3^{\circ} / \mathrm{min}$., The requisite amount of glycerol was added directly to chick-embryo tissues, which were then shaken and cooled to $-79^{\circ}$ in a storage chest containing solid carbon dioxide. The infectivity of stored chick-embryo materials was tested in mice and in embryonated eggs. After passage in eggs, harvested materials were examined for infectivity in mice. These experiments are summarized in Table 2.

\section{DISCUSSION}

In his review, Weinman (1944) recorded no conclusive reports of the cultivation of eperythrozoa in bacteriological media or in tissue cultures; he suggested that claims to have cultivated species of the closely related genus Haemobartonella should be cautiously assessed. Eperythrozoon suis was carried for one passage in the yolk sacs of embryonated eggs (Splitter, 1952), and single passages of Eperythrozoon coccoides were also made in the amniotic fluids and yolk sacs of eggs (Derrick et al. 1954); in each case the organisms did not survive further passages. Kessler (1942) failed to cultivate Haemobartonella muris in the yolk sacs of embryonated eggs, but Vogelsang \& Gallo (cited by Weinman, 1944) claimed to have carried this organism for one passage on the chorioallantoic membrane. In the present study, $E$. coccoides was successfully propagated in embryonated eggs inoculated by the yolk sac and intravenous routes. Although eperythrozoa were detected in blood and spleen smears taken from infected embryos, the organisms were not detected with certainty in yolk-sac smears. Yolk sac and chick-embryo blood were always infective for mice, and no change in infectivity was observed during the successive passages. $E$. coccoides was present in $10^{-6}$ dilutions of the yolk sac from two of the later passages. Gledhill, Dick \& Andrewes (1952) and Gledhill, Dick \& Niven, 1955), using a similar diluent, found that $E$. coccoides could be passaged in $10^{-8}$ dilutions of a suspension of mouse liver and spleen.

The successful cultivation of Eperythrozoon coccoides in embryonated eggs suggests that these are at present the most suitable media for the cultivation of other species of Eperythrozoon and perhaps of Haemobartonella. Cultivation should facilitate the study of these organisms by obviating the present need to work continually with experimental animals of the host species. In particular, investigations into the site of multiplication of eperythrozoa and certain aspects of their host-parasite relationship might be conducted in chick embryos, where the absence of many external complicating factors would prove advantageous. 
Eperythrozoon coccoides and $E$. suis have been preserved for short periods at temperatures near $0^{\circ}$ (Weinmann, 1944; Thurston, 1955; Biberstein, Barr, Larrow \& Roberts, 1956). E. suis survived for at least 31 days in defibrinated blood stored at $\mathbf{- 3 2}^{\circ}$ (Splitter, 1952), and Haemobartonella muris survived for at least 11 weeks in defibrinated rat blood after rapid cooling to $-79^{\circ}$ (Kessler, 1942). The present results indicate that $-79^{\circ}$ may be the most satisfactory temperature for the storage of $E$. coccoides. Although the organisms sometimes survived storage at $-79^{\circ}$ in chick-embryo tissues without added glycerol, these inocula were not always infective for mice and embryonated eggs. It would appear, therefore, that the presence of $10 \%$ glycerol is a worthwhile adjunct.

I am most grateful to Dr A. O. Betts for his advice and encouragement during the course of this work, and to Miss A. Hyde for capable technical assistance. The work was carried out during the tenure of a Crookes Research Fellowship.

\section{REFERENCES}

Beveridge, W. I. B. \& Burnett, F. M. (1946). The cultivation of viruses and rickettsiae in the chick embryo. Spec. Rep. Ser. med. Res. Counc., Lond. no. 256.

Biberstein, E. L., Barr, L. M., Larrow, L. L. \& Roberts, S. J. (1956). Eperythrozoonosis of swine in New York State. Cornell Vet. 46, 288.

Craigie, J. (1949). A pressure mincer for the preparation of tumour suspensions. Brit. J. Cancer, 3, 249.

Derrick, E. H., Pope, J. H., Chong, S. K., Carley, J. G. \& Lee, P. E. (1954). Observations on infection of mice with Eperythrozoon coccoides Schilling. Aust. J. exp. Biol. med. Sci. 32, 577 .

Gledhill, A. W., Dick, G. W. A. \& Andrewes, C. H. (1952). Production of hepatitis in mice by the combined action of two filterable agents. Lancet, ii, 509 .

Gledhild, A. W., Dick, G. W. A. \& Niven, J. S. F. (1955). Mouse hepatitis virus and its pathogenic action. J. Path. Bact. 69, 299.

Kessler, W. R. (1942). Preservation of Bartonella muris in the frozen state. Proc. Soc. exp. Biol., N.Y. 49, 238.

SplitTER, E. J. (1952). Eperythrozoonosis in swine-Filtration studies. Amer. J. vet. Res. 13, 290.

Thunston, J. P. (1955). Observations on the course of Eperythrozoon coccoides infections in mice, and the sensitivity of the parasite to external agents. Parasitology, 45, 141.

Weinman, D. (1944). Infectious anaemias due to Bartonella and related red cell parasites. Trans. Amer. phil. Soc. 33, 243.

(Received 26 February 1959) 